\title{
Behavioral Perspective on Investor's Reaction to Mergers and Acquisitions Announcements
}

\author{
Neethu T C, Rajeesh Viswanathan, Arun T C, Jahira Parveen
}

\begin{abstract}
The study focuses at mergers and acquisitions (M\&As) in India and explains the shareholder's value creation using stock return data from 2005 to 2016. The data analyzed with the use of market model of event study. The deals classified into cash-financed and stock-financed on the basis of mode of payment. The results suggest that the reaction towards the M\&As announcements are spontaneous in Indian economy and the shareholders gaining positively around the M\&As announcement on an average. Shareholders of cash financed deals are creating more value than that of the stock financed deals.
\end{abstract}

Index Terms: Mergers and Acquisitions, Stock Return, Event Study, Mode of Payment

\section{INTRODUCTION}

M\&A is one of the most important organizational events and it is very complex in nature. In M\&As the acquired company paid with the acquisition premium by the acquirer. The amount of premium is depends on the expected synergetic value and the mode of payment. The premium can be paid with cash, stock, and mix of cash and stock. The company should pay the tax on capital gain in the same year of cash financed M\&As deals, but the capital gain tax can be delayed till the sale of new shares. Due to this tax effect the premium is higher in case of cash financed M\&As deals (Carleton et al., 1983). The existing literature replete with stock price reaction towards the M\&As announcements, we know little about the role of mode of payment in stock price reaction or shareholder's value creation.

The present study intends to test the shareholders reaction towards the M\&As announcements as a whole, as well as the shareholders reaction to cash-financed deals and stock-financed deals separately. The methodology used to test the stock price reaction is event study which is based on the assumption of efficient market hypothesis propounded by Fama (1970) and he explained that the stock price reflects all the information that is publically available. The present study found that the shareholders gained positive return around the M\&As announcements and the cash financed deals and stock-financed deals are different in case of the shareholder's value creation. The stock price reaction to the cash-financed deals are positive around the M\&As announcements and the

Revised Manuscript Received on July 05, 2019.

Neethu T C, Dept of International Business, School of Management, Pondicherry University, Pondicherry

Dr. Rajeesh Viswanathan, Asst Prof, Dept of International Business, School of Management, Pondicherry University, Pondicherry.

Arun T C, Department of Management, School of Management, Pondicherry University, Karaikal Campus,Karaikal, India

Dr. Jahira Parveen, Faculty of Management, SRM Institute of Technology, Chennai. stock price reaction towards the stock-financed deals are negative.

\section{REVIEW OF LITERATURE AND HYPOTHESIS BUILDING}

Fama (1970) explains the stock price reflects all the information available to the shareholders. He assumes the investors value the stock rationally. The shareholders are not making decision in a vacuum, and they consider other's perceptions too (Barberis and Thaler, 2003). The management hold richer information about the M\&As decisions than the investors (Jennings and Mezzeo, 1991). The shareholders lose their value due to the M\&As (King et al., 2004). Langetieg (1978)argues the shareholders reacts negatively to the M\&As announcements. On the contrary, Moeller and Schlingemann, (2005); Faccio et al., (2006); Masulis et al., (2007) argue that around an M\&A announcement the shareholders gaining positively. Based on these arguments we frame a hypothesis that the stock price reaction towards the M\&As announcements is positive.

$\mathrm{H}_{1}$ : The shareholders makes positive gain around the $M \& A s$ announcements.

The existing literature replete with stock price reaction towards the M\&As announcements, we know little about the role of mode of payment in stock price reaction or shareholder's value creation. Schijven and Hitt (2012) argues that the mode of payment inform the investors about the expected synergy. There are studies which argues that the cash-financed deals makes more value to the shareholders than the stock-financed deals (Ghosh, 2001; Linn and Switzer, 2001; Haleblian et al., 2009). The deals financed with stock are more risky than the deals financed with cash (Martin, 1996). Thus the investors are more confident on cash-financed deals than stock-financed deals.

$\mathrm{H}_{2}$ : The cash-financed deals makes more value to the shareholders than the stock financed deals.

\section{DATA AND METHODOLOGY}

\section{Sample Selection}

The present study focuses on the 543 M\&As occurred in India during 20065-2017. The details on the deal have been extracted from the Thomson Reutres M\&As database, and the stock price data form BSE website. The acquirers without the stock price data have been excluded from the list. The sample comprise of 374 cash financed deals and 179 stock financed deals.

Event Study

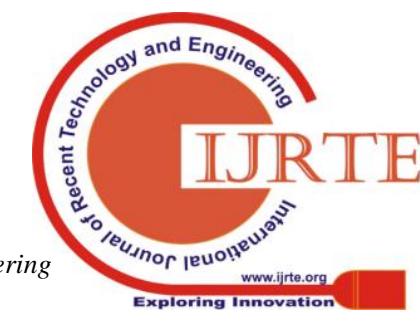


The event study methodology has been widely used since its inception in 1960s in strategic management. It helps to extract the impact of organizational events. The present study uses market model of event study methodology to test the stock market reaction around the M\&As announcements. The market model use to estimate the parameters is:

Where,

$$
R_{i t}=\alpha_{i}+\beta_{i,} \times R_{m t}+e_{i t}
$$

$\mathrm{R}_{\mathrm{it}}=$ the rate of return

$\alpha_{\mathrm{i}}=$ the intercept

$\beta_{\mathrm{i}}$, = the slope of the linier relation between stock return and return of market

$\mathrm{R}_{\mathrm{mt}}=$ return on the market portfolio

$\mathrm{e}_{\mathrm{it}}=$ error term

The abnormal return is estimated using the following formula:

Where,

$$
A R_{i t}=R_{i t}-\left({ }^{\wedge} \alpha_{i}+{ }^{\wedge} \beta_{i,} \times{ }^{\wedge} R_{m t}\right)
$$

$\mathrm{AR}_{\mathrm{it}}$ is abnormal return. Abnormal return is calculated by deducting the expected return from the actual return. The daily abnormal return then aggregates over the event window to calculate the cumulative abnormal return (CAR).

This study uses five event windows to estimate the stock market reaction towards the M\&As announcements. Three days window $(-1,+1)$, five days window $(-2,+2)$, seven days window $(-3,+3)$, eleven days window $(-5,+5)$, and twenty one $\mathrm{t}$ test used to check the statistical difference of CAR from zero.

\section{RESULTS AND DISCUSSION}

Stock Price Reaction around M\&As Announcements

Table 1 shows the stock market reaction around the M\&As announcements in India. On an average the shareholders of acquiring firms makes positive gain around the M\&As announcements. The stock market nor reacts significantly in immediate day $(-1,+1)$ of the M\&As announcements. This may be due to the information asymmetry. Otherwise the stock market have a behavior of immediate reaction to the organizational events. But in five days window (3.207), seven days window (4.587), and twenty one days window (6.147) the shareholders makes positive gain.

Table 1. Stock Price Reaction to the M\&As

\begin{tabular}{|c|c|c|c|}
\hline \\
\hline $\begin{array}{l}\text { Event } \\
\text { Windows }\end{array}$ & Mean & S.D & t-stat \\
\hline$(-10,+10)$ & 0.0030 & 0.00225 & $6.147^{* *}$ \\
\hline$(-5,+5)$ & 0.0014 & 0.00290 & 1.609 \\
\hline$(-3,+3)$ & 0.0033 & 0.00335 & $\mathbf{4 . 5 8 7}^{* *}$ \\
\hline$(-2,+2)$ & 0.0035 & 0.00359 & $3.207^{* * *}$ \\
\hline$(-1,+1)$ & 0.0045 & 0.00399 & 1.933 \\
\hline
\end{tabular}
Announcements

Stock Price Reaction around M\&As AnnouncementsCash-Financed Deals

Table 2 represent the stock price reaction towards cash-financed M\&As announcements. The results clearly advocates that the shareholders have confidence in the cash-financed M\&As. The shareholders make positive abnormal return during three days window (7.193), five days days window $(-10,+10)$ are used in this study. The parametric

window (4.096), and seven days window (2.948). But in comparatively long window i.e., twenty one day window $(-2.401)$ the return is significantly negative. The information which is publically available has significant role in the shareholders reaction. It is clear that the shareholders change their investing decision in long term. It may be due to the information available to the investors on immediate days after M\&As announcements are not rich.

\begin{tabular}{|l|l|l|l|}
\hline \multicolumn{4}{|c|}{$\begin{array}{l}\text { Table 2. Stock Price Reaction to the M\&As } \\
\text { Announcements - Cash-Financed Deals }\end{array}$} \\
\hline $\begin{array}{l}\text { Event } \\
\text { Windows }\end{array}$ & Mean & S.D & t-stat \\
\hline$(-10,10)$ & -.0014 & .00265 & $\mathbf{- 2 . 4 0 1}$ \\
\hline$(-5,5)$ & .0000 & .00314 & 0.049 \\
\hline$(-3,3)$ & .0040 & .00356 & $\mathbf{2 . 9 4 8}$ \\
\hline$(-2,2)$ & .0061 & .00334 & $\mathbf{4 . 0 9 6}^{* * * *}$ \\
\hline$(-1,1)$ & .0066 & .00159 & $\mathbf{7 . 1 9 3}^{* * *}$ \\
\hline \multicolumn{4}{|c|}{$* * *, * *$ Significant at $1 \%$ and $5 \%$ level } \\
\hline
\end{tabular}

Stock Price Reaction around M\&As Announcements stock-Financed Deals

Table 3 presents the results of stock price reaction to the stock -Financed M\&As announcements. The shareholders of Indian acquirers reacts negatively to the stock financed deals and they make negative return around the M\&As announcements. As stated above the information asymmetry plays here also significantly. The shareholders reaction to M\&As announcements is insignificant in three days windows and five days window. In seven days window (-2.429), eleven days window (-5.709), and twenty one days window (-5.362) the stock price reaction is significantly negative. That is the shareholders reacts to the stock financed M\&As announcements negatively.

\begin{tabular}{|l|l|l|l|}
\hline \multicolumn{4}{|c|}{$\begin{array}{c}\text { Table 3. Stock Price Reaction to the M\&As } \\
\text { Announcements - Stock-Financed Deals }\end{array}$} \\
\hline $\begin{array}{l}\text { Event } \\
\text { Windows }\end{array}$ & Mean & S.D & t-stat \\
\hline$(-10,10)$ & -.0168 & .01438 & $\mathbf{- 5 . 3 6 2}$ \\
\hline$(-5,5)$ & -.0166 & .00966 & $\mathbf{- 5 . 7 0 9}$ \\
\hline$(-3,3)$ & -.0045 & .00493 & $\mathbf{- 2 . 4 2 9}$ \\
\hline$(-2,2)$ & -.0008 & .00286 & -0.648 \\
\hline$(-1,1)$ & .0011 & .00189 & 0.980 \\
\hline \multicolumn{4}{|c|}{$* * *$ * Significant at 1\% and $10 \%$ level } \\
\hline
\end{tabular}

Stock Price Reaction around M\&As Announcements Cash-Financed vs Stock-Financed

The difference in stock market reaction between cash financed deals and stock financed deals depicted in Table 4. The results clearly advocate that there is significant difference between cash financed and stock financed deals in stock price reaction. The shareholders of cash- financed M\&As deals make more benefit than the shareholders of stock-financed M\&As deals. In all the event windows the difference between cash-financed and stock-financed deals are significant. It is because the acceptance of cash-financed M\&As than stock-financed M\&As in investors. Because of the risk factor in the stock-financed M\&As deals the shareholders believe that the cash-financed deals can bring expected synergetic gain. 


\begin{tabular}{|l|l|l|l|}
\hline \multicolumn{4}{|c|}{$\begin{array}{l}\text { Table 4. Stock Price Reaction to the M\&As } \\
\text { Announcements - Cash vs Stock Financed Deals }\end{array}$} \\
\hline $\begin{array}{l}\text { Event } \\
\text { Windows }\end{array}$ & Mean & S.D & t-stat \\
\hline$(-10,10)$ & .01544 & .01358 & $\mathbf{5 . 2 1 0}$ *** \\
\hline$(-5,5)$ & .01667 & .01034 & $\mathbf{5 . 3 4 6}^{* * *}$ \\
\hline$(-3,3)$ & .00850 & .00654 & $\mathbf{3 . 4 3 8}^{* * *}$ \\
\hline$(-2,2)$ & .00694 & .00467 & $\mathbf{3 . 3 2 6}^{* * *}$ \\
\hline$(-1,1)$ & .00552 & .00180 & $\mathbf{5 . 3 1 3}$ \\
\hline \multicolumn{4}{|c|}{$* * *, *$ Significant at 1\% and $5 \%$ level } \\
\hline
\end{tabular}

\section{CONCLUSION}

The study aims at examining the shareholders behavioral perspective towards the M\&As announcements. With the use of event study methodology we found that the shareholders yield positive return around the M\&As announcements, on an average. There is information asymmetry in Indian capital market, since the results shows no significant reaction to the M\&As announcements within immediate days. The study also analyses whether the shareholders reaction differ according to the mode of payment. The cash-financed M\&As deals makes value to the shareholders on the other hand the stock-financed M\&As deals makes lose to the shareholders. On short windows the stock market reacts positively to the cash-financed M\&As announcements and negatively to the long window. The stock-financed deals doesn't make value to the shareholders but makes loss during long windows. The risk element in stock- financed deals makes the shareholders less confident about the stock-financed deals. The cash-financed deals and stock-financed deals are dissimilar. The share holders makes positive return when the deals are financed with cash and loss otherwise.

\section{REFERENCES}

1. Barberis, N., \& Thaler, R. (2003). A survey of behavioral finance. Handbook of the Economics of Finance, 1, 1053-1128.

2. Carleton, W. T., Guilkey, D. K., Harris, R. S., \& Stewart, J. F. (1983). An empirical analysis of the role of the medium of exchange in mergers. The Journal of Finance, 38(3), 813-826.

3. Faccio, M., \& Stolin, D. (2006). Expropriation vs. proportional sharing in corporate acquisitions. The Journal of Business, 79(3), 1413-1444.

4. Ghosh, A. (2001). Does operating performance really improve following corporate acquisitions?. Journal of corporate finance, 7(2), 151-178.

5. Haleblian, J., Devers, C. E., McNamara, G., Carpenter, M. A., \& Davison, R. B. (2009). Taking stock of what we know about mergers and acquisitions: A review and research agenda. Journal of management, 35(3), 469-502.

6. Jennings, R. H., \&Mazzeo, M. A. (1991). Stock price movements around acquisition announcements and management's response. Journal of Business, 139-163.

7. King, D. R., Dalton, D. R., Daily, C. M., \&Covin, J. G. (2004). Meta-analyses of post-acquisition performance: Indications of unidentified moderators. Strategic management journal,25(2), 187-200.

8. Langetieg, T. C. (1978). An application of a three-factor performance index to measure stockholder gains from merger. Journal of Financial Economics, 6(4), 365-383.

9. Linn, S. C., \& Switzer, J. A. (2001). Are cash acquisitions associated with better postcombination operating performance than stock acquisitions?. Journal of Banking \& Finance, 25(6), 1113-1138.

10. Malkiel, B. G., \& Fama, E. F. (1970). Efficient capital markets: A review of theory and empirical work. The journal of Finance, 25(2), 383-417.

11. Martin, K. J. (1996). The method of payment in corporate acquisitions, investment opportunities, and management ownership. The Journal of finance, 51(4), 1227-1246.
12. Masulis, R. W., Wang, C., \& Xie, F. (2007). Corporate governance and acquirer returns. The Journal of Finance, 62(4), 1851-1889.

13. Moeller, S. B., \& Schlingemann, F. P. (2005). Global diversification and bidder gains: A comparison between cross-border and domestic acquisitions. Journal of Banking \& Finance, 29(3), 533-564.

14. Schijven, M., \& Hitt, M. A. (2012). The vicarious wisdom of crowds: Toward a behavioral perspective on investor reactions to acquisition announcements. Strategic Management Journal, 33(11), 1247-1268. 